\title{
REFORMULASI DANA DESA UNTUK MEWUJUDKAN TRANSFER BERBASIS KINERJA: MOMENTUM PENINGKATAN PERAN DI MASA PANDEMI
}

\author{
Khoirunurrofik \\ Yusuf Reza Kurniawan \\ Ghany Ellantia Wiguna \\ Universitas Indonesia \\ Alamat Korespondensi: khoirunurrofik@ui.ac.id
}

\begin{abstract}
Even though the formula has been refined several times, the issue of effectiveness and fulfilment of the criteria for justice from the Village Fund Allocation is still a big question in Indonesia's public finance policy. This study aims to reformulate the allocation of Village Funds based on evaluating the current formula's weaknesses and identifying potential new indicators to increase effectiveness and equality, particularly in increasing the role of Village Funds in the Village Economic Recovery during the Pandemic Covid-19 Period. The study used a descriptive analysis approach through a literature review, focus group discussion, and secondary data analysis. The study results conclude that it is necessary to reduce the weight of the Basic Allocation for minimizing the imbalance in the amount of the Village Fund allocation. It is also suggested to increase the Formula Allocation weight to ensure that the Village Fund allocation is in accordance with each village's needs and capacities, encouraging a more equitable and effective distribution. In addition, the weight of Affirmation Allocation needs to be increased in the short term but then gradually decreases in the following period to prevent moral hazard. Furthermore, to encourage village independence, the Performance Allocation needs to be increased as a reward mechanism for villages that have good performance. This study recommends that the Village Fund allocation formula's improvement should be carried out periodically and thought to the SDGs Targets and Indicators that can be implemented at the village level.
\end{abstract}

\begin{abstract}
ABSTRAK
Meskipun telah mengalami beberapa kali penyempurnaan formula, persoalan efektivitas dan pemenuhan kriteria keadilan dari alokasi Dana Desa masih menjadi pertanyaan besar dalam kebijakan keuangan publik di Indonesia. Tujuan penelitian ini adalah melakukan reformulasi pengalokasian Dana Desa berdasarkan evaluasi terhadap kelemahan formula saat ini dan identifikasi potensi indikator baru untuk meningkatkan efektivitas dan keadilan terutama peningkatan peran Dana Desa bagi Pemulihan Ekonomi Desa di Masa Pandemi Covid-19. Penelitian ini menggunakan pendekatan deskriptif analisis melalui kajian literatur, focus group discussion, dan analisis data sekunder. Hasil penelitian menyimpulkan perlunya menurunkan bobot Alokasi Dasar untuk mengurangi ketimpangan besaran alokasi Dana Desa dan menaikkan bobot Alokasi Formula untuk memastikan alokasi Dana Desa yang sesuai dengan kebutuhan dan kapasitas masing-masing desa sehingga mendorong alokasi yang lebih berkeadilan dan efektif. Sementara itu, bobot Alokasi Afirmasi perlu dinaikkan dalam jangka pendek, namun kemudian menurun secara gradual di periode setelahnya untuk mencegah timbulnya moral hazard. Selanjutnya untuk mendorong pencapaian kemandirian desa, Alokasi Kinerja perlu dinaikkan sebagai mekanisme reward bagi desa-desa yang memiliki kinerja baik. Rekomendasi dari kajian ini adalah penyempurnaan formula alokasi Dana Desa perlu dilakukan secara periodik serta perlu memperhatikan target dan indikator SDGs yang dapat diimplementasikan di tingkat desa.
\end{abstract}

\section{Kata Kunci:}

Reformulasi, Dana Desa, Kapasitas Fiskal, Keadilan, Pemerataan

\section{KLASIFIKASI JEL:}

010, 023, E62

\section{CARA MENGUTIP:}

Khoirunurrofik, Kurniawan, Y, R, \& Wiguna, G E. (2021). Reformulasi dana desa untuk mewujudkan transfer berbasis kinerja: momentum peningkatan peran di masa pandemi. Indonesian Treasury Review: Jurnal Perbendaharaan, Keuangan Negara dan Kebijakan Publik, 6(1), 43-56. 


\section{PENDAHULUAN}

Kesenjangan pembangunan antara desa dan kota masih menjadi masalah besar di Indonesia. Dari total 25,1 juta penduduk miskin di Indonesia, sekitar 15,1 juta orang di antaranya tinggal di daerah perdesaan (BPS, 2019). Proporsi penduduk miskin di wilayah perdesaan yang mencapai 12,8 persen juga jauh lebih tinggi dibandingkan dengan wilayah perkotaan yang hanya sebesar 6,69 persen. Dari sisi pendidikan dan kesehatan, penduduk desa juga cenderung lebih tertinggal dibandingkan dengan penduduk kota. Relatif terhadap penduduk kota, masyarakat desa rata-rata mengenyam pendidikan 2 tahun lebih singkat dan persentase penduduk dengan akses sanitasi layak adalah 11 persen lebih rendah (BPS, 2019).

Di tahun 2015, Pemerintah mengeluarkan kebijakan Dana Desa dalam rangka mempercepat pengentasan kemiskinan perdesaan melalui memberikan sumber daya fiskal tambahan bagi desa. Kebijakan Dana Desa juga merupakan wujud nyata perubahan paradigma pengaturan desa yang menjadikan desa tidak lagi hanya sebagai objek pembangunan, namun kini menjadi subjek dan ujung tombak pembangunan dan peningkatan kesejahteraan masyarakat desa.

Undang-Undang Nomor 6 Tahun 2014 tentang Desa (selanjutnya disebut UU Desa) menjelaskan bahwa dana desa yang berasal dari Anggaran Pendapatan dan Belanja Negara (APBN) dihitung berdasarkan jumlah desa dan dialokasikan dengan mempertimbangkan jumlah penduduk, angka kemiskinan, luas wilayah, dan tingkat kesulitan geografis desa. Formula alokasi Dana Desa berperan penting dalam memastikan pemerataan pembangunan desa mengingat kondisi sosial, ekonomi, dan geografis desa-desa di Indonesia sangat bervariasi.

Alokasi Dana Desa yang diterima oleh tiap-tiap desa saat ini dinilai masih belum sepenuhnya mencerminkan prinsip keadilan dan dianggap masih kurang efektif dalam mendukung pemerataan pembangunan dan peningkatan akses masyarakat miskin terhadap layanan publik (KOMPAK, 2017; Lewis, 2015). Terdapat ketimpangan dalam besaran dana yang diterima dengan jumlah penduduk miskin; daerah dengan jumlah penduduk miskin yang rendah namun memiliki jumlah desa yang banyak akan memperoleh alokasi dana desa yang jauh lebih besar dari daerah dengan jumlah penduduk miskin tinggi namun jumlah desanya relatif sedikit (KOMPAK, 2017).

Kebijakan Dana Desa juga dinilai belum efektif dalam mendorong pengentasan kemiskinan desa (Imawan \& Purwanto, 2020) dan membuka lapangan kerja (Arifin dkk, 2020). Dalam konstruksi formula alokasi saat ini, komponen insentif yang berfungsi mendorong peningkatan kinerja tata kelola pemerintahan desa memiliki bobot yang lebih rendah dari komponen afirmasi yang lebih bersifat pemerataan.

Selanjutnya, analisis kebijakan anggaran dan transfer saat ini tidak dapat dilepaskan dari situasi pandemi Covid-19. Undang-Undang Nomor 2 Tahun 2020 tentang Penetapan Peraturan Pemerintah Pengganti Undang-Undang (Perppu) Nomor 1 Tahun 2020 Tentang Kebijakan Keuangan Negara dan Stabilitas Sistem Keuangan untuk Penanganan Pandemi Corona Virus Disease 2019 (Covid-19) dan/atau dalam Rangka Menghadapi Ancaman yang Membahayakan Perekonomian Nasional dan/atau Stabilitas Sistem Keuangan menjadi UndangUndang menjelaskan di Pasal 2 ayat (1) huruf I bahwa penyesuaian pagu anggaran Dana Desa adalah dengan pengutamaan penggunaan Dana Desa yang antara lain dapat digunakan untuk bantuan langsung tunai kepada penduduk miskin di desa dan kegiatan penanganan pandemi Covid-19.

Pandemi Covid-19 telah mengubah tatanan perencanaan dan penganggaran pembangunan nasional dan daerah. Kinerja ekonomi yang menurun tajam akibat terganggunya konsumsi serta berhentinya proses produksi di tingkat nasional maupun global menyebabkan ekspor dan impor mengalami kontraksi dan mengakibatkan pertumbuhan ekonomi menurun tajam. Pemerintah telah menerapkan berbagai kebijakan pembatasan fisik dan sosial dalam rangka meminimalisasi penyebaran virus Sars-Cov-2. Di samping itu, kebijakan pembatasan tentu membutuhkan dukungan anggaran untuk membiayai berbagai bantuan sosial yang harus dikeluarkan oleh pemerintah untuk mengurangi dampak hilangnya pendapatan masyarakat. Untuk itu, strategi realokasi dan pemfokusan ulang anggaran dimana kebijakan anggaran (termasuk di dalamnya Dana Desa) tidak hanya ditujukan untuk meminimalisasi dampak Covid-19 tetapi juga untuk menstimulasi proses pemulihan ekonomi Indonesia.

Penelitian ini bertujuan untuk menyusun konsep formula baru pengalokasian Dana Desa yang lebih mencerminkan aspek keadilan serta mampu mendorong percepatan pengentasan kemiskinan desa dan perbaikan kinerja tata kelola desa. Hal ini terutama dibutuhkan dalam rangka percepatan pemulihan ekonomi desa dan sekaligus mengurangi dampak pandemi Covid-19.

Untuk dapat menyusun formula baru perlu dilakukan evaluasi terhadap formula alokasi Dana Desa yang berlaku saat ini, serta melakukan identifikasi atas indikator-indikator baru yang berpotensi dapat digunakan dalam formula baru pengalokasian Dana Desa. Guna memenuhi tujuan tersebut, kajian ini akan dibagi menjadi tiga bagian. Di bagian pertama berupa evaluasi terhadap 
kebijakan dana desa secara keseluruhan. Bagian kedua memberikan usulan perbaikan terhadap formula pengalokasian Dana Desa berdasarkan analisis di bagian sebelumnya. Bagian terakhir akan menjelaskan potensi pemanfaatan Dana Desa dalam rangka meminimalisasi dampak pandemi di wilayah perdesaan. Adapun metode yang digunakan dalam studi ini adalah kajian literatur, analisis data sekunder, dan focus group discussion (FGD) dengan pemangku kepentingan terkait.

Artikel ini selanjutnya disusun dengan sistematika berikut. Bagian 2 menggambarkan kerangka konseptual dari kebijakan Dana Desa berdasarkan tinjauan pustaka dan melakukan komparasi dengan kebijakan serupa di negara lain. Bagian 3 menjelaskan metode penelitian yang digunakan. Bagian 4 memberikan analisis atas hasil penelitian. Bagian 5 memberikan kesimpulan dan rekomendasi kebijakan.

\section{LANDASAN TEORI}

\subsection{Tinjauan Pustaka}

Desentralisasi —dalam bentuk paling idealdidefinisikan sebagai suatu upaya memberdayakan masyarakat lokal melalui penguatan peran pemerintah daerah yang dipilih oleh masyarakat (Bahl \& Bird, 2018). Desentralisasi di sisi fiskal menuntut pemerintah pusat untuk menyerahkan sebagian kewenangan pengambilan keputusan terkait anggaran dan belanja kepada pemerintah di level sub nasional atau lebih dikenal dengan istilah devolusi.

Dari perspektif teori, desentralisasi di satu sisi dapat memperbaiki penyediaan layanan publik di daerah karena pemerintah daerah cenderung lebih paham terhadap preferensi dan kebutuhan masyarakat lokal (Oates, 1999) dan secara geografis lebih dekat dengan masyarakat sehingga biaya penyediaan layanan publik lebih rendah (Campbell dkk, 1991; Tiebout, 1956). Desentralisasi juga dapat mendorong perbaikan tata kelola pemerintahan di daerah dengan cara menjadikan pemerintah daerah lebih akuntabel dan responsif terhadap kebutuhan masyarakat di daerahnya (Faguet, 2014) dan meningkatkan efisiensi penyelenggaraan layanan publik (Sow \& Razafimahefa, 2015).

Pelimpahan kewenangan kepada daerah sendiri tidak serta-merta akan selalu memberikan dampak yang positif apabila pemberdayaan fiskal (fiscal empowerment) tersebut tidak diiringi dengan pemberdayaan politis (political empowerment). Hal ini berlaku terutama ketika pelimpahan wewenang lebih banyak di sisi pengeluaran daripada penerimaan (Bahl \& Bird, 2018).

Mardiasmo (2019) mengemukakan prinsip dan tujuan desentralisasi fiskal sebagai instrumen kebijakan pemerintah sebagai berikut: a. Mengurangi vertikal fiscal imbalance dan horizontal fiscal imbalance;

b. Meningkatkan kualitas pelayanan publik di daerah dan mengurangi kesenjangan pelayanan publik antar daerah;

c. Meningkatkan efisiensi peningkatan sumber daya nasional;

d. Tata kelola, transparan, dan akuntabel dalam pelaksanaan kegiatan pengalokasian transfer ke daerah yang tepat sasaran; dan

e. Mendukung kesinambungan fiskal dalam kebijakan ekonomi makro.

UU Desa mengamanatkan adanya alokasi APBN yang dibagikan ke desa berdasarkan kriteria tertentu (Penjelasan Pasal 72 UU Desa). Alokasi Dana Desa tersebut merupakan bagian dari komponen transfer fiskal pemerintah pusat kepada pemerintah daerah dalam kerangka Transfer Ke Daerah dan Dana Desa (TKDD). Alokasi Dana Desa bertujuan untuk meningkatkan kesejahteraan dan pemerataan pembangunan desa. Dengan adanya alokasi dana khusus tersebut, diharapkan pemerintahan desa dapat meningkatkan efektivitas program berbasis desa secara merata dan berkeadilan.

Dalam prinsip keuangan publik, kebijakan transfer pusat ke daerah (termasuk di dalamnya adalah Dana Desa) perlu mempertimbangkan kriteria efisiensi dan keadilan (Broadway \& Shah, 2007). Dalam kriteria efisiensi yang mengutamakan penanggulangan kemiskinan, alokasi Dana Desa dikatakan efisien jika distribusi yang tercipta dapat mendorong perbaikan kesejahteraan penduduk miskin di desa tanpa memperburuk kesejahteraan penduduk lain. Sedangkan dalam kriteria keadilan, alokasi harus memenuhi keadilan horizontal dan keadilan vertikal. Dalam keadilan horizontal, desa yang karakteristiknya sama (jumlah penduduk, tingkat kemiskinan, luas wilayah dan sebagainya) sepatutnya menerima alokasi Dana Desa dalam jumlah yang sama, sedangkan dalam keadilan vertikal, desa yang memiliki kebutuhan lebih besar (tingkat kemiskinan yang lebih tinggi, kondisi geografis yang sulit), seharusnya menerima alokasi yang lebih besar. Prinsip keadilan secara horizontal dan vertikal ini harus lebih tercermin dalam formula pengalokasian Dana Desa.

Di konteks Indonesia, selain melihat prinsip keadilan, maka pengalokasian Dana Desa juga perlu memperhatikan aspek pemerataan (UU Desa Pasal 72 Ayat 2). Karakteristik desa di Indonesia yang sangat beragam menjadikan pemenuhan aspek pemerataan dan keadilan cenderung saling berlawanan. Alokasi yang menitikberatkan pada aspek pemerataan akan menghasilkan distribusi Dana Desa yang cenderung tidak merata, sementara alokasi yang berfokus pada pemenuhan aspek keadilan cenderung menciptakan distribusi Dana Desa dengan variasi yang sangat tinggi antara satu 
desa dengan desa yang lain (Lewis, 2015). Alasan ini kemungkinan menjadi dasar penyesuaian bobot aspek pemerataan yang semakin menurun dalam formula alokasi Dana Desa, sementara di saat yang sama aspek keadilan semakin meningkat.

Formula pengalokasian Dana Desa diatur melalui Peraturan Menteri Keuangan (PMK). Aturan tersebut menetapkan komponen yang menentukan besaran Dana Desa yang diterima suatu desa. Pada awal penerapan, alokasi Dana Desa hanya ditentukan berdasarkan dua komponen: Alokasi Dasar dan Alokasi Formula (PMK 49/2016) dengan rasio bobot 90:10. Selanjutnya, pemerintah menambah komponen Alokasi Afirmasi ke dalam formula alokasi Dana Desa sebagai bentuk pemenuhan aspek keberpihakan dalam kebijakan Dana Desa (PMK 199/2017). Perbaikan terakhir atas formula alokasi Dana Desa dilakukan dengan menambahkan komponen Alokasi Kinerja yang merefleksikan aspek kinerja dengan memberikan insentif bagi daerah yang memiliki kinerja tata kelola baik (PMK 205/2019).

Berdasarkan tinjauan literatur di atas, maka penyempurnaan atas formula alokasi Dana Desa perlu mempertimbangkan 4 (empat) aspek, yaitu aspek pemerataan, aspek keadilan, aspek keberpihakan, dan aspek insentif kinerja sebagaimana diilustrasikan dalam Gambar 1. Selanjutnya, untuk mengetahui bagaimana praktik kebijakan transfer fiskal dari pemerintah pusat ke pemerintah di tingkat desa secara langsung, maka di bagian selanjutnya akan dijelaskan mengenai perbandingan praktik kebijakan serupa di beberapa negara.

\subsection{Praktik Internasional}

Kebijakan transfer dana secara langsung dari pemerintah pusat ke pemerintah tingkat desa dapat dijumpai di beberapa negara. Di Thailand, kebijakan dana transfer ke desa dikenal dengan nama Village Fund dengan tujuan awal sebagai dana bantuan usaha mikro di desa namun saat ini dialihkan menjadi dana pembangunan infrastruktur desa. Di India, kebijakan dana desa dikenal sebagai FFC Basic and Performance Grant dimana penggunaan dana diperuntukkan untuk memenuhi standar minimum layanan sanitasi dan penyediaan air bersih. Di Nepal, terdapat dana untuk desa bernama Village Development Community Unconditional Grant untuk membiayai belanja modal dan operasional pemerintahan desa. Berbeda dengan ketiga negara, dana desa di Bangladesh yang dikenal dengan $A D P$ Grant tidak memiliki prasyarat khusus dalam penggunaan dana desa sehingga penggunaan dana desa sepenuhnya menjadi wewenang desa.

\footnotetext{
${ }^{1}$ Pemilihan K/L sebagai narasumber berdasarkan Surat Keputusan Bersama 4 Menteri Dalam Percepatan Pelaksanaan Undang-Undang Nomor 6 Tahun 2014 tentang Desa.
}

Tabel 1 memberikan rangkuman komparasi internasional terkait dengan kebijakan transfer dana dari pemerintah pusat ke desa. Besaran dana yang diterima masing-masing desa di negaranegara tersebut ditentukan berdasarkan formula tertentu. Di titik paling ekstrem, Thailand menetapkan bobot alokasi dasar sebesar 100 persen sehingga besaran dana yang diterima tiaptiap desa berjumlah sama. Di titik ekstrem sebaliknya, Nepal mengalokasikan 100 persen dana atas dasar alokasi formula yang mempertimbangkan jumlah penduduk, luas wilayah, dan indeks kemahalan konstruksi masingmasing desa. Di spektrum antara dua titik ekstrem tersebut, India dan Bangladesh menetapkan alokasi formula dan alokasi kinerja dengan masing-masing bobot 90 persen dan 10 persen. Indikator yang digunakan dalam alokasi formula di India adalah jumlah penduduk dan luas wilayah, sedangkan Bangladesh menambah indikator indeks ketertinggalan desa. Pada alokasi kinerja, kedua negara menggunakan indikator yang sama yaitu kualitas alokasi dana, manajemen keuangan, performa pendapatan desa, dan transparansi dalam penggunaan dana (UNDP, 2019).

\section{METODOLOGI PENELITIAN}

Studi ini bertujuan untuk melakukan reformulasi atas metode pengalokasian Dana Desa sehingga dapat menciptakan distribusi Dana Desa yang berkeadilan, mencerminkan keberpihakan, mendorong kemajuan pembangunan desa, dan meningkatkan kinerja tata kelola desa. Metode analisis yang digunakan dalam studi ini meliputi studi literatur, analisis statistik deskriptif berdasarkan data sekunder, dan analisis kualitatif berdasarkan informasi yang diperoleh dari focus group discussion (FGD).

Informasi yang digunakan sebagai dasar analisis dalam studi ini diperoleh dari 5 (lima) seri diskusi kelompok terarah yang diselenggarakan pada bulan Juli sampai dengan September 2020. Secara khusus, seri diskusi tersebut bertujuan untuk mendapatkan evaluasi secara menyeluruh tentang proses formulasi Dana Desa, yang mencakup prinsip dan konsep pelaksanaan, landasan hukum, perencanaan, formulasi dan mekanisme distribusi, penggunaan dan capaian, pendataan, pengelolaan di tingkat desa, monitoring dan evaluasi, serta isu dan tantangan yang dihadapi. Narasumber diskusi berasal dari institusi pemerintahan yang berkaitan dengan kebijakan Dana Desa dan akademisi antara lain ${ }^{1}$ :

a. Kementerian Desa, Pembangunan Daerah Tertinggal, dan Transmigrasi (Kemendesa), 
b. Kementerian Perencanaan Pembangunan Nasional/Bappenas (Bappenas),

c. Kementerian Keuangan (Kemenkeu),

d. Kementerian Dalam Negeri (Kemendagri), dan

e. Akademisi dari Fakultas Ekonomi dan Bisnis dan Fakultas Ilmu Administrasi Universitas Indonesia.

Secara garis besar, hasil diskusi tersebut adalah sebagai berikut:

a. Komponen Alokasi Dasar secara umum tetap layak untuk dipertahankan mengingat perannya sebagai komponen pemerataan. Namun bobot Alokasi Dasar yang ada sekarang masih dirasa terlalu tinggi. Komponen Alokasi Dasar yang terlalu tinggi dapat menyebabkan timbulnya alokasi yang kurang berkeadilan.

b. Terdapat dua opsi yang muncul dalam pembahasan mengenai perbaikan atas komponen Alokasi Dasar. Opsi pertama adalah menurunkan bobot komponen Alokasi Dasar. Opsi ini memperbaiki alokasi Dana Desa sehingga lebih berkeadilan, namun memiliki potensi penolakan yang besar dari desa, khususnya dari desa-desa yang mengalami penurunan besaran total Dana Desa yang diterima. Opsi kedua adalah melakukan klasterisasi desa sebagai basis penentuan besaran Alokasi Dasar. Klasterisasi dilakukan berdasarkan jumlah penduduk suatu desa. Dengan demikian, Alokasi Dasar yang diterima desa berpenduduk besar tidak sama dengan yang diterima oleh desa berpenduduk kecil. Dengan opsi ini, alokasi Dana Desa per kapita yang diterima oleh masing-masing desa akan lebih seimbang. Akan tetapi, penggunaan indikator jumlah penduduk dalam proses klasterisasi dapat memunculkan isu double counting mengingat indikator tersebut juga dipakai dalam menghitung Alokasi Formula. Diperlukan analisis lebih lanjut berbasis data untuk memperkirakan bagaimana klasterisasi memengaruhi distribusi Dana Desa secara keseluruhan.

c. Penurunan bobot Alokasi Dasar juga sebaiknya diikuti dengan peningkatan bobot Alokasi Formula. Secara definisi Alokasi Formula telah mempertimbangkan variasi antar desa dalam menghitung berapa alokasi Dana Desa yang akan diterima oleh masing-masing desa. Dalam formula saat ini, variabel yang dipertimbangkan antara lain jumlah penduduk, jumlah penduduk miskin, luas wilayah, dan indeks kesulitan geografis. Selain menaikkan bobot Alokasi Formula secara langsung, terdapat pula opsi memasukkan komponen Alokasi Afirmasi dan Alokasi Kinerja ke dalam Alokasi Formula. d. Untuk komponen Alokasi Afirmasi, pembahasan difokuskan pada potensi moral hazard yang timbul dari adanya komponen ini dalam formula alokasi Dana Desa. Dengan bobot yang ada sekarang, desa-desa berstatus Desa Tertinggal dan Desa Sangat Tertinggal berhak menerima tambahan Dana Desa dalam bentuk Alokasi Afirmasi. Besaran yang diterima per desa cukup signifikan sehingga desa-desa yang sudah menerima Alokasi Afirmasi cenderung enggan untuk lepas dari status Desa Tertinggal atau Desa Sangat Tertinggal. Salah satu opsi perbaikan yang mengemuka untuk komponen Alokasi Afirmasi adalah menurunkan bobot komponen ini dalam formula. Namun patut dipertimbangkan juga bagaimana pengaruh turunnya alokasi Dana Desa terhadap efektivitas Dana Desa dalam mengentaskan kemiskinan di desa-desa tertinggal. Opsi lain adalah dengan meningkatkan bobot Alokasi Afirmasi dalam jangka pendek, namun secara gradual bobot tersebut diturunkan. Kenaikan Alokasi Afirmasi diharapkan menjadi modal awal upaya pengentasan kemiskinan di desa-desa tertinggal, namun adanya penurunan di periode-periode selanjutnya meminimalisasi potensi moral hazard.

e. Komponen Kinerja merupakan komponen baru di dalam formula alokasi Dana Desa. Komponen ini baru digunakan pada tahun 2020 dan diharapkan mampu memberikan insentif bagi desa-desa untuk meningkatkan kinerja tata kelola Dana Desa dan pembangunan desa. Dalam kondisi saat ini, besaran Alokasi Kinerja yang diterima per desa masih dianggap terlalu kecil untuk bisa memengaruhi perilaku pemerintahan desa agar meningkatkan kinerjanya. Opsi perbaikan yang muncul untuk komponen Alokasi Kinerja adalah kenaikan bobot Alokasi Kinerja dalam formula.

\section{HASIL PENELITIAN}

\subsection{Analisis Kinerja Pemerataan dan Kapasitas}

Berlakunya Undang-Undang Nomor 6 Tahun 2014 tentang Desa menjadi titik awal desa sebagai subjek dan berpartisipasi di dalam pembangunan dan peningkatan kesejahteraan masyarakat. Dalam prosesnya, desa mendapatkan transfer fiskal dari pemerintah sesuai dengan Peraturan Pemerintah Nomor 60 Tahun 2014, yang kemudian disebut sebagai Dana Desa. Dana Desa dianggarkan di dalam APBN setiap tahunnya. Desa dapat mengelola dana desa secara mandiri selama tidak bertentangan dengan peraturan perundangan yang berlaku. Besaran Dana Desa untuk tiap kabupaten dihitung berdasarkan jumlah desa, sementara pengalokasian ke masing-masing desa dilakukan dengan 
mempertimbangkan jumlah penduduk, angka kemiskinan, luas wilayah, dan tingkat kesulitan geografis. Adapun tujuan adanya dana desa adalah sebagai berikut:

- Meningkatkan pelayanan publik di desa

- Mengentaskan kemiskinan

- Memajukan perekonomian desa

- Mengatasi masalah kesenjangan pembangunan antar desa

- Memperkuat masyarakat desa sebagai subjek pembangunan

Alokasi anggaran Dana Desa terus mengalami peningkatan setiap tahun, dari Rp20,7 triliun di 2015 hingga mencapai Rp71,2 triliun di 2020. Dengan demikian, jika pada 2015 rata-rata desa menerima sebesar Rp280 juta, maka di 2020 tiap desa diperkirakan dapat memperoleh Dana Desa sebesar Rp950 juta.

UU Desa mengamanatkan pendistribusian Dana Desa yang merata dan berkeadilan. Untuk itu, pemerintah terus melakukan penyempurnaan formula pengalokasian Dana Desa. Pada formula alokasi Dana Desa yang berlaku selama tiga tahun pertama (2015-2017), Dana Desa dialokasikan dengan ketentuan 90 persen anggaran Dana Desa dibagikan secara merata ke seluruh desa sebagai Alokasi Dasar, sementara 10 persen tersisa dialokasikan dengan mempertimbangkan jumlah penduduk, tingkat kemiskinan, luas wilayah, dan kesulitan geografis sebagai Alokasi Formula (formula 90/10). Dengan demikian, alokasi Dana Desa diharapkan dapat memenuhi asas pemerataan (melalui Alokasi Dasar) dan keadilan (Alokasi Formula).

Pada praktiknya, proporsi Alokasi Dasar yang mencapai 90 persen tersebut justru tidak mencerminkan keadilan (KOMPAK, 2017; Lewis, 2015; World Bank, 2017). Lewis (2015) menemukan penerapan formula 90/10 mendorong distribusi Dana Desa yang tidak adil. Variasi jumlah penduduk, jumlah penduduk miskin, luas wilayah dan tingkat kesulitan geografis memberikan konsekuensi bahwa kebutuhan daerah cenderung bersifat heterogen sehingga besarnya porsi Alokasi Dasar justru mendorong desa tidak menerima alokasi dana yang sesuai dengan kebutuhannya.

Perbandingan distribusi Dana Desa yang diterima per desa berdasarkan formula 90/10 dengan formula variabel dimana bobot Alokasi Formula sebesar 100 persen (formula variabel) menunjukkan hal tersebut. Formula 90/10 menghasilkan sebaran jumlah Dana Desa yang relatif lebih seragam. Dengan kata lain, desa-desa berukuran besar dengan jumlah penduduk dan jumlah penduduk miskin yang besar akan menerima Dana Desa dalam jumlah yang tidak jauh berbeda dengan desa-desa yang memiliki jumlah penduduk lebih sedikit. Di sisi lain, formula variabel menghasilkan distribusi yang lebih heterogen. Perhitungan menggunakan alokasi formula didasarkan atas faktor jumlah penduduk, jumlah penduduk miskin, luas wilayah dan tingkat kesulitan geografis. Desa dengan jumlah penduduk tinggi akan mendapat Dana Desa yang lebih tinggi, begitu juga dengan desa yang memiliki jumlah penduduk miskin tinggi akan mendapat dana desa yang lebih tinggi.

Selanjutnya, Lewis (2015) mencoba mengukur kesalahan alokasi Dana Desa tahun 2015 dengan cara menghitung perbedaan dari alokasi yang diterima desa dengan formula 90/10 dengan alokasi yang seharusnya didapat desa jika memperhitungkan kebutuhan fiskal desa. Studi tersebut menunjukkan adanya ketimpangan alokasi Dana Desa dimana beberapa daerah mendapatkan alokasi yang lebih rendah dan lebih tinggi dari yang seharusnya. Indonesia bagian timur menjadi daerah yang paling dirugikan karena daerah tersebut menerima dana desa 70 persen lebih rendah dari yang seharusnya, sedangkan Kalimantan menjadi daerah yang paling diuntungkan karena mendapatkan Dana Desa sebesar dua kali lipat dari yang seharusnya (Lihat Gambar 2).

Studi KOMPAK (2017) menemukan bahwa pengalokasian Dana Desa yang dilakukan dengan formula 90/10 cenderung kurang proporsional terhadap jumlah penduduk dan jumlah penduduk miskin. Sebanyak 34 persen atau 27 juta penduduk miskin dan hampir miskin tinggal di 10 persen desa dengan besaran Dana Desa per kapita paling kecil (Lihat Gambar 3).

Studi kasus di dua desa dengan karakteristik berbeda menunjukkan adanya ketimpangan alokasi Dana Desa (World Bank, 2017). Tabel 2 dan Tabel 3 memperlihatkan indikator karakteristik serta alokasi Dana Desa di Desa Bengkaung dan Desa Pusuk Lestari. Kabupaten Lombok Barat merupakan kabupaten tertinggal demikian pula Desa Bengkaung dan Desa Pusuk Lestari merupakan desa tertinggal berdasarkan nilai Indeks Desa Mandiri (IDM). Kedua desa dipilih karena terletak di kecamatan yang sama namun memiliki karakteristik yang berbeda. Meskipun memiliki karakteristik yang berbeda, kedua desa tersebut mendapat Dana Desa yang relatif sama sehingga, dengan jumlah penduduk yang berbeda, kedua desa mendapat Dana Desa per penduduk yang berbeda pula dengan perbandingan hampir 1:3 antara Desa Bengkaung dan Desa Pusuk Lestari.

Selain tidak memperhatikan karakteristik desa, pengalokasian Dana Desa juga tidak memperhatikan sumber pendapatan desa lainnya seperti Alokasi Dana Desa dan Bagi Hasil Pajak dan Retribusi Daerah. Implikasinya, total pendapatan desa per penduduk antara Desa Bengkaung dan Desa Pusuk Lestari timpang dengan perbandingan 
hampir 1:3. Ketimpangan pada jumlah dana desa per penduduk dan total pendapatan desa per penduduk antara kedua desa tersebut mengakibatkan ketimpangan pada pelayanan dasar antar kedua desa. Setiap Posyandu di Bengkaung secara rata-rata melayani 53 anak usia 0-4 tahun, sementara di Pusuk Lestari melayani 27 anak.

Penurunan tren alokasi dasar dan meningkatnya alokasi formula dari tahun ke tahun telah menunjukkan upaya pemerintah untuk meningkatkan aspek keadilan secara bertahap dengan tetap memperhatikan aspek pemerataan. Namun demikian, masih diperlukan terobosan yang lebih cepat dan tepat untuk meningkatkan efektivitas Dana Desa mencapai tujuan-tujuan yang diamanatkan oleh Undang-Undang Desa, terutama adalah dengan mengurangi bobot alokasi formula yang telah terbukti tidak tepat menjawab kebutuhan pendanaan terutama di desa yang padat penduduk, luas wilayah besar, tingkat kemiskinan tinggi, serta berada di lokasi geografis yang sulit. Oleh karena itu, strategi reformulasi Dana Desa adalah penting dan harus dilakukan dengan mempertimbangkan secara komprehensif terkait dengan komposisi yang tepat antara alokasi dasar, formula, afirmasi dan insentif.

\subsection{Strategi Reformulasi Dana Desa}

Komponen yang membentuk alokasi Dana Desa saat ini diatur dalam Peraturan Menteri Keuangan dan terdiri dari Alokasi Dasar, Alokasi Formula, Alokasi Afirmasi, dan Alokasi Kinerja. Pada dasarnya, masing-masing jenis alokasi tersebut dapat kita sandingkan dengan prinsip alokasi yang diamanatkan UU Desa, yaitu pemerataan, keadilan, keberpihakan, dan insentif. Secara spesifik, aspek pemerataan dicerminkan oleh Alokasi Dasar, aspek keadilan oleh Alokasi Formula, aspek keberpihakan oleh Alokasi Afirmasi, dan aspek insentif oleh Alokasi Kinerja.

Alokasi Dasar masih patut dipertahankan karena merupakan cerminan dari prinsip pemerataan dalam penyelenggaraan Dana Desa. Namun demikian, masih dominannya komponen Alokasi Dasar di dalam formula alokasi menyebabkan efektivitas Dana Desa dalam menciptakan alokasi yang adil kurang optimal. Untuk itu, usulan perbaikan terhadap Alokasi Dasar adalah dengan menurunkan bobot komponen ini di dalam formula. Berdasarkan analisis pada bagian sebelumnya, bobot Alokasi Dasar dalam formula pengalokasian Dana Desa sebaiknya diturunkan sehingga berada pada nilai 50 persen.

Turunnya bobot Alokasi Dasar perlu diiringi dengan naiknya bobot Alokasi Formula. Langkah ini diperkirakan dapat menciptakan alokasi Dana Desa

\footnotetext{
${ }^{2}$ Berapa lama jangka waktu yang ideal bagi Alokasi Afirmasi merupakan isu yang krusial dan di luar cakupan dari studi ini.
}

yang lebih adil, karena pengaruh faktor karakteristik desa dalam menentukan besaran dana yang diterima suatu desa menjadi lebih besar. Mengingat porsi Alokasi Dasar diusulkan sebesar 50 persen, maka Alokasi Formula dapat dinaikkan hingga mencapai 45 persen.

Secara sederhana, untuk mendorong distribusi Dana Desa yang lebih adil (besaran dana mencerminkan kondisi dan kebutuhan desa) namun tetap memiliki unsur pemerataan (besaran dana awal yang sama untuk seluruh desa), maka Alokasi Dasar turun 19 persen dan Alokasi Formula naik 17 persen. Dalam formula baru ini, selisih bobot antara Alokasi Dasar dan Alokasi Formula lebih kecil dari selisih dalam formula lama. Dengan demikian, aspek keadilan yang tercermin dari Alokasi Formula memiliki pengaruh yang hampir sama dengan aspek pemerataan yang tercermin dari Alokasi Dasar dalam menentukan besaran Dana Desa yang diterima suatu desa.

Berdasarkan telaah literatur dan hasil diskusi, studi ini juga menyarankan dilakukannya perbaikan terhadap komponen yang menentukan besaran Alokasi Formula. Selama ini Alokasi Formula dihitung berdasarkan kombinasi jumlah penduduk, angka kemiskinan, luas wilayah, dan tingkat kesulitan geografis. Penyempurnaan lebih lanjut atas komponen formula tersebut dapat dilakukan dengan memasukkan indikator kapasitas dan potensi fiskal desa.

Alokasi Afirmasi merupakan cerminan dari unsur keberpihakan kepada desa-desa yang relatif lebih tertinggal. Dengan adanya alokasi ini, desadesa yang memiliki kapasitas fiskal yang lebih lemah dibandingkan desa-desa lain dapat memperoleh tambahan Dana Desa dari Alokasi Afirmasi. Dalam formula saat ini, bobot Alokasi Afirmasi ditetapkan sebesar 1,5 persen. Berdasarkan analisis bagian sebelumnya, bobot Alokasi Afirmasi dapat ditingkatkan menjadi 2,5 persen. Alokasi Afirmasi yang lebih besar merupakan salah satu upaya untuk mendorong percepatan pengentasan kemiskinan di desa-desa yang relatif tertinggal.

Namun demikian, Alokasi Afirmasi sebaiknya tidak dimaksudkan untuk terus ada dalam jangka panjang. Karena alokasi ini diperuntukkan bagi desa-desa yang relatif tertinggal, maka idealnya jumlah desa yang berhak memperoleh alokasi ini akan terus mengalami penurunan dari tahun ke tahun. Untuk itu, dalam skema baru, Alokasi Afirmasi sebaiknya disertai dengan ketentuan mengenai jangka waktu maksimal satu desa dapat menerima alokasi tersebut ${ }^{2}$. Dalam jangka panjang, Alokasi Afirmasi perlu dititikberatkan pada desadesa berkarakteristik khusus seperti desa di daerah 
3TP (Terpencil, Terluar, Terdepan, dan Perbatasan) atau desa dengan risiko bencana tinggi.

Alokasi Kinerja merupakan bentuk insentif bagi desa yang berhasil meningkatkan tata kelola pemerintahan di wilayahnya. Dalam formula saat ini, alokasi ini memiliki bobot 1,5 persen. Berdasarkan analisis dan diskusi, bobot Alokasi Kinerja dapat ditambah hingga menjadi 2,5 persen. Kenaikan ini diperkirakan dapat mendorong desadesa untuk memperbaiki kinerja tata kelola mereka. Ke depan, ruang perbaikan bagi komponen Alokasi Kinerja dalam formula alokasi Dana Desa adalah melalui peningkatan bobot komponen Alokasi Kinerja secara gradual. Dalam kerangka formula saat ini, Alokasi Kinerja belum memberikan dampak optimal dalam peningkatan kinerja desa karena, dengan bobot saat ini, besaran Alokasi Kinerja yang diterima tiap desa jauh lebih kecil dari besaran Alokasi Afirmasi. Dengan kata lain, reward bagi desa yang berhasil meningkatkan kinerja lebih kecil dibandingkan dengan tambahan dana yang diperoleh dari status desa tertinggal.

Dalam jangka panjang, untuk mengoptimalkan dampak dari Alokasi Kinerja terhadap peningkatan tata kelola desa, maka dapat disusun rencana kenaikan bobot Alokasi Kinerja secara gradual. Dengan demikian, seiring berjalannya waktu, reward atas kinerja pengelolaan desa yang baik akan semakin besar. Selain itu, terdapat ruang perbaikan atas indikator penilaian kinerja misalnya melalui penyelarasan indikator Alokasi Kinerja dengan Tujuan dan Indikator SDGs yang menjadi kewenangan desa.

\subsection{Penguatan Peran Dana Desa dalam Mengatasi Dampak Pandemi Covid-19 di Wilayah Perdesaan}

Pandemi Covid-19 yang tengah berjalan sejak awal tahun 2020 telah memberikan dampak negatif yang besar terhadap kondisi sosio-ekonomi masyarakat. Pandemi Covid-19 juga memengaruhi penyelenggaraan kebijakan Dana Desa di tahun 2020. Dampak pertama adalah penurunan pagu anggaran Dana Desa sebesar Rp810 miliar dari sebelumnya sebesar Rp72 triliun menjadi Rp71,19 triliun. Dengan demikian, alokasi Dana Desa yang diterima oleh tiap-tiap desa juga mengalami penurunan. Hal ini merupakan implikasi dari kebijakan penggunaan alokasi anggaran untuk kegiatan tertentu (refocusing), penyesuaian alokasi, dan/atau pemotongan/penundaan penyaluran anggaran Transfer ke Daerah dan Dana Desa untuk penanganan Covid-19 dan stimulus fiskal untuk mengurangi dampak ekonomi atas Covid-19 tersebut.

Dalam perkembangannya, kebijakan Dana Desa juga menjadi salah satu instrumen Pemerintah Indonesia dalam menanggulangi dampak negatif dari pandemi Covid-19 khususnya terhadap warga miskin di wilayah perdesaan sebagai bagian dari kebijakan "pengutamaan penggunaan Dana Desa" sesuai amanat Undang-Undang (UU) Republik Indonesia Nomor 2 Tahun 2020. Dalam konteks penanggulangan dampak pandemi, sebagian dari Dana Desa yang diterima oleh desa dapat digunakan untuk jaring pengaman sosial dalam bentuk Bantuan Langsung Tunai (BLT) Desa atau kegiatan penanganan pandemi lain di desa. Jenis kegiatan lain tersebut antara lain: pengadaan bahan kebutuhan pokok bagi penduduk desa terdampak, pengadaan bahan dan alat kesehatan, atau kegiatan lainnya sesuai ketentuan yang berlaku.

Untuk bantuan dalam bentuk BLT Desa, target sasaran penerima diprioritaskan bagi keluarga miskin atau tidak mampu yang berdomisili di desa dan tidak termasuk sebagai penerima bantuan lain dari pemerintah baik pusat maupun daerah. Dengan demikian, dalam konteks pandemi kebijakan Dana Desa diarahkan sebagai komplemen dari kebijakankebijakan pemerintah yang lain. Selain dari sisi sosial, kebijakan Dana Desa terkait dengan penanganan pandemi juga diarahkan untuk program Padat Karya Tunai Desa (PKTD). Program ini dapat dipandang sebagai upaya pemerintah dalam menangani dampak negatif pandemi terhadap penciptaan lapangan kerja dengan menjaga daya beli masyarakat desa.

Kedua kebijakan tersebut dapat menjadi stimulus ekonomi dimana pemerintah desa mencoba mendorong agar pemanfaatan Dana Desa tersebut dapat berdampak langsung dengan mempercepat proses pembangunan masyarakat desa dan dapat memberikan dampak bagi ekonomi lokal serta menciptakan kemandirian lokal di tingkat desa yang berkesinambungan. Dampak dari aktivitas ekonomi lokal adalah kemampuan masyarakat meningkat sehingga mempunyai daya beli dan melakukan konsumsi, yang pada akhirnya dapat mendorong peningkatan kesejahteraan masyarakat desa. Selain itu, refocusing Dana Desa dapat diarahkan untuk menciptakan wirausaha desa, yaitu orang-orang yang melakukan kegiatan kewirausahaan dengan mendirikan unit industri dan bisnis di sektor ekonomi pedesaan (Kulkarni \& Narkhede, 2016).

\section{KESIMPULAN DAN SARAN}

\subsection{Kesimpulan}

Secara umum penyelenggaraan Dana Desa telah memberikan banyak manfaat bagi kemajuan desa khususnya dari sisi peningkatan infrastruktur desa. Akan tetapi, pengalokasian Dana Desa juga berpotensi menghambat kemandirian desa apabila pemberian Dana Desa tersebut meningkatkan ketergantungan sehingga mengurangi keinginan desa untuk meningkatkan Pendapatan Asli Desa dan melepaskan desa dari dukungan dana 
ketertinggalan. Oleh karena itu, kerangka formulasi Dana Desa perlu disusun agar tujuan utama penyelenggaraan Dana Desa tetap bisa tercapai menjadi penting. Dengan menyadari adanya keanekaragaman desa di Indonesia, komponen formulasi Dana Desa perlu mempertimbangkan prinsip pemerataan, keadilan, keberpihakan, serta berbasis kinerja. Dari hasil evaluasi, dapat disimpulkan bahwa isu dan tantangan formulasi Dana Desa saat ini bukan dari penambahan komponen formula tetapi bagaimana penentuan bobot masing-masing komponen tersebut sehingga alokasi Dana Desa bisa lebih efektif dalam mencapai tujuan kebijakannya terutama dalam meningkatkan peran sebagai stimulus fiskal di tingkat desa.

Komponen-komponen formulasi Dana Desa saat ini-Alokasi Dasar, Alokasi Formula, Alokasi Afirmasi dan Alokasi Kinerja-secara umum telah memenuhi prinsip pemerataan sebagai modal dasar dalam pembangunan, konsep keadilan yang memperhatikan keragaman, keberpihakan terhadap desa agar dapat mengejar ketertinggalan serta berbasis kinerja sebagai insentif bagi desa untuk terus meningkatkan kinerja tata kelolanya. Namun demikian, masih ada beberapa catatan dan ruang perbaikan di dalam komponen-komponen tersebut. Sebagai contoh, selain pertimbangan kondisi sosial, ekonomi dan geografis desa, Alokasi Formula juga perlu melihat kapasitas dan potensi fiskal desa.

Untuk meminimalisasi ketergantungan desa terhadap Dana Desa di dalam anggaran, maka penentuan bobot dari komponen-komponen formula alokasi Dana Desa menjadi penting. Prinsip dan tujuan utama Dana Desa yang menjadikan desa sebagai ujung tombak pembangunan harus tetap menjadi pedoman, sehingga perlu melihat keseimbangan antara pemerataan dan keadilan serta antara keberpihakan dengan kinerja. Keseimbangan antara pemerataan dan keadilan dapat dicapai melalui penurunan bobot Alokasi Dasar secara gradual yang diimbangi dengan kenaikan bobot Alokasi Formula. Implementasi prinsip keberpihakan melalui Alokasi Afirmasi yang berpotensi mendorong keengganan desa untuk terlepas dari ketertinggalan perlu diimbangi dengan pemberian Alokasi Kinerja sebagai insentif bagi desa untuk meningkatkan kinerja tata kelola desa.

Pemberian Alokasi Afirmasi juga harus disertai dengan exit strategy sehingga tidak menimbulkan moral hazard bagi desa-desa penerima, misalnya dengan pemberian tenggat waktu terhadap Alokasi Afirmasi yang diterima suatu desa. Ke depan, Alokasi Afirmasi perlu tetap ada sebagai cerminan keberpihakan pada desa-desa dengan karakteristik khusus, misalnya desa di wilayah Tertinggal, Terpencil, Terluar, dan Perbatasan (3TP).
Alokasi Kinerja diperlukan sebagai skema insentif bagi desa-desa untuk meningkatkan kinerja tata kelola mereka. Alokasi Kinerja belum berdampak optimal karena dengan bobot komponen saat ini besaran yang diterima per desa jauh lebih kecil dibandingkan dengan besaran per desa yang diterima dari Alokasi Afirmasi. Optimalisasi dampak Alokasi Kinerja dapat dilakukan dengan menaikkan bobot komponen secara gradual. Indikator-indikator penilaian kinerja juga perlu terus disempurnakan dengan mempertimbangkan kewenangan desa. Selain itu, pemberian Alokasi Kinerja juga perlu diikuti dengan upaya peningkatan kapasitas sumber daya manusia pada pemerintahan desa.

\subsection{Rekomendasi}

Dalam reformulasi Dana Desa perlu dibentuk peta jalan (roadmap) yang menggambarkan kesinambungan dan sinergi antar kebijakan dalam proses perencanaan pembangunan nasional yaitu peran Dana Desa dalam pembangunan nasional dalam hal ini Rencana Pembangunan Jangka Menengah Nasional (RPJMN), penyusunan roadmap formulasi Dana Desa, arahan penggunaannya setiap tahun untuk capaian pembangunan jangka menengah hingga pengelolaannya di tingkat desa. Hal ini agar penyelenggaraan Dana Desa lebih efektif dalam pencapaian tujuan pembangunan nasional secara umum maupun penempatan desa sebagai ujung tombak pembangunan. Roadmap pengembangan formula alokasi Dana Desa dalam jangka menengah dapat dilihat di Gambar 4.

Selain itu, dengan adanya rencana pembangunan nasional yang telah selaras dengan pencapaian SDGs, maka pemanfaatan Dana Desa juga harus bisa mendukung pencapaian indikator SDGs. Perbaikan desain alokasi dan penggunaan Dana Desa juga dapat diselaraskan dengan tujuan dan target SDGs. Dalam hal ini, kebijakan Dana Desa dapat dirancang sebagai salah satu instrumen pemerintah dalam mendukung pencapaian SDGs khususnya di tingkat desa. Kementerian Desa, Pembangunan Daerah Tertinggal, dan Transmigrasi (Kemendesa) saat ini tengah mengkaji bagaimana mendudukkan kebijakan Dana Desa ke dalam kerangka SDGs melalui penyusunan SDGs Desa Plus. Sejauh ini, Kemendesa telah mengadaptasi 17 Tujuan SDGs sehingga relevan untuk diaplikasikan di tingkat desa.

Upaya selanjutnya dalam proses adaptasi SDGs ke tingkat desa di atas adalah dengan menjabarkan ketujuh belas tujuan SDGs Desa Plus tersebut ke dalam Target dan Indikator yang lebih detail. Sebagai langkah awal dalam mendukung adopsi SDGs ke dalam kebijakan Dana Desa, maka dilakukan pemetaan terhadap indikator-indikator SDGs Nasional yang berpotensi digunakan dalam formula alokasi Dana Desa. Dari 319 indikator SDGs 
Nasional, sekitar 56 indikator di antaranya dapat dicapai dengan dukungan dan peran serta desa.

\section{IMPLIKASI DAN KETERBATASAN}

Studi ini menunjukkan perlu adanya perbaikan reformulasi Dana Desa dalam rangka meningkatkan efektivitas Dana Desa tersebut bagi kesinambungan proses pembangunan di desa terutama secara spesifik dihubungkan dengan target-target SDGs. Reformulasi yang meningkatkan bobot formula diharapkan akan meningkatkan keadilan dan pemerataan kemampuan pendanaan pembangunan desa yang pada akhirnya akan mampu mendorong ketertinggalan desa-desa yang belum mandiri menjadi semakin maju dan mandiri.

Namun demikian studi ini perlu dilanjutkan dalam simulasi empiris untuk menunjukkan tingkat optimal bobot komponen formula untuk terciptanya keadilan dan pemerataan antar desa. Studi ini masih memili keterbatasan terhadap akses data-data desa yang lebih mikro untuk melakukan simulasi secara lengkap di tingkat desa.

\section{DAFTAR PUSTAKA}

Arifin, B., Wicaksono, E., Tenrini, R. H., Wardhana, I. W., Setiawan, H., Damayanty, S. A., Solikin, A., Suhendra, M., Saputra, A. H., Ariutama, G. A., Djunedi, P., Rahman, A. B., \& Handoko, R. (2020). Village fund, village-ownedenterprises, and employment: Evidence from Indonesia. Journal of Rural Studies, 79, 382394.

https://doi.org/10.1016/j.jrurstud.2020.08.0 52.

Bahl, R., \& Bird, R. M. (2018). Fiscal decentralization and local finance in developing countries: Development from below. In Fiscal Decentralization and Local Finance in Developing Countries: Development from Below. https://doi.org/10.4337/9781786435309.

BPS. (2019). Profil Kemiskinan di Indonesia Maret 2019 (Issue 56/07/Th. XXII).

Broadway, R., \& Shah, A. (2007). Intergovernmental fiscal transfers: Principles and practices. The World Bank.

Campbell, T., Peterson, G., \& Brakarz, J. (1991). Decentralization to local government in LAC: National strategies and local response in planning, spending, and management. http://documents.worldbank.org/curated/en /750711491958459630/Decentralization-tolocal-government-in-LAC-national-strategiesand-local-response-in-planning-spendingand-management.

Faguet, J. P. (2014). Decentralization and governance. World Development, 53, 2-13. https://doi.org/10.1016/j.worlddev.2013.01. 002 .

Imawan, S. A., \& Purwanto, E. A. (2020). Governing village fund in Indonesia: Is it eradicating poverty? Policy \& Governance Review, 4(1), 14. https://doi.org/10.30589/pgr.v4i1.169.

Kementerian Keuangan. (2017). Peraturan Menteri Keuangan Nomor 199/PMK.07/2017 tentang Tata Cara Pengalokasian Dana Desa Setiap Kabupaten/Kota dan Penghitungan Rincian Dana Desa Setiap Desa.

Kementerian Keuangan. (2018). Peraturan Menteri Keuangan Nomor 193/PMK.07/2018 tentang Pengelolaan Dana Desa.

Kementerian Keuangan. (2019). Peraturan Menteri Keuangan Nomor 205/PMK.07/2019 tentang Pengelolaan Dana Desa.

KOMPAK. (2017). Dana Desa dan Penanggulangan Kemiskinan. Diakses dari https://kompak.or.id /id/article/analisis-kebijakan-dana-desa-danpenanggulangan-kemiskinan pada tanggal 9 Maret 2021.

Kulkarni, S. M., Narkhede, P. A., \& Jalgaon, J. (2016). Entrepreneurship and rural development. Rural Development: Trends, Opportunities and Challenges in 21st Century, 23-30.

Lewis, B. D. (2015). Decentralizing to villages in Indonesia: money (and other) mistakes. Public Administration and Development, 35(5), 347359. https://doi.org/10.1002/pad.1741.

LPEM FEB UI. (2020). Kajian Reformulasi Pengalokasian Dana Desa.

Mardiasmo. (2004). Otonomi dan manajemen keuangan daerah. Yogyakarta: Andi.

Oates, W. E. (1999). An easy on fiscal federalism. Journal of Economic Literature, 37(3), 40.

Republik Indonesia. (2014). Undang Undang Nomor 6 Tahun 2014 Tentang Desa.

Republik Indonesia. (2020). Undang-Undang (UU) Republik Indonesia Nomor 2 Tahun 2020 tentang Penetapan Peraturan Pemerintah Pengganti Undang-Undang (Perpu) Nomor 1 Tahun 2020 Tentang Kebijakan Keuangan Negara dan Stabilitas Sistem Keuangan untuk Penanganan Pandemi Corona Virus Disease 2019 (Covid-19) dan/atau dalam Rangka Menghadapi Ancaman yang Membahayakan Perekonomian Nasional dan/atau Stabilitas Sistem Keuangan menjadi Undang-Undang.

Sow, M., \& Razafimahefa, I. (2015). Fiscal decentralization and the efficiency of public service delivery. In IMF Working Papers (Vol. 
15 , Issue 59).

https://doi.org/10.5089/9781484351116.00

1.

Tiebout, C. M. (1956). A pure theory of local expenditures. Journal of Political Economy, 64(5), 416-424.

https://doi.org/10.1086/257839.

UNDP. (2019). Fiscal transfers in Asia: Challenges and opportunities for financing sustainable development at the local level | UNDP. UNDP. https://www.undp.org/content/undp/en/ho me/librarypage/poverty-reduction/fiscaltransfer-in-asia.html.

World Bank. (2017). Dana Desa Reguler dan Afirmasi: Sejumlah Pemikiran. 


\section{ILUSTRASI TABEL}

Tabel 1. Komparasi Internasional Praktik Transfer Dana dari Pusat ke Desa

\begin{tabular}{|c|c|c|c|}
\hline Negara & Nama Program & Tujuan Program & Komponen Formula \\
\hline Thailand & $\begin{array}{l}\text { Village and Urban } \\
\text { Community Fund (VF) }\end{array}$ & Pembangunan infrastruktur desa. & $\begin{array}{l}\text { Alokasi Dasar: } \mathbf{1 0 0 \%} \\
\text { (Seluruh desa mendapat alokasi sama) }\end{array}$ \\
\hline India & $\begin{array}{l}\text { FFC Basic Grant and } \\
\text { Performance Grant }\end{array}$ & $\begin{array}{l}\text { Membantu desa dalam memberikan } \\
\text { standar minimum layanan publik } \\
\text { terutama dalam aspek sanitasi dan } \\
\text { penyediaan air. }\end{array}$ & $\begin{array}{l}\text { Alokasi Formula: } \mathbf{9 0 \%} \\
\text { - } 90 \% \text { Jumlah Penduduk } \\
\text { - } 10 \% \text { Luas Wilayah } \\
\text { Alokasi Kinerja: } \mathbf{1 0 \%} \\
\text { - Alokasi dana } \\
\text { - Manajemen keuangan } \\
\text { - Performa pendapatan desa } \\
\text { - Transparansi }\end{array}$ \\
\hline Bangladesh & $\begin{array}{l}\text { Annual Development } \\
\text { Program (ADP) Grant }\end{array}$ & $\begin{array}{l}\text { Bantuan keuangan untuk desa dalam } \\
\text { bentuk block grant dimana } \\
\text { penggunaan dana diserahkan ke } \\
\text { desa. }\end{array}$ & $\begin{array}{l}\text { Alokasi Formula: } \mathbf{9 0 \%} \\
\text { - } 50 \% \text { Jumlah Penduduk } \\
\text { - } 30 \% \text { Luas Wilayah } \\
\text { - } 20 \% \text { Indeks Ketertinggalan Desa } \\
\text { Alokasi Kinerja: } \mathbf{1 0 \%} \\
\text { - Alokasi dana } \\
\text { - Manajemen keuangan } \\
\text { - Performa pendapatan desa } \\
\text { - Transparansi }\end{array}$ \\
\hline Nepal & $\begin{array}{l}\text { Village Development } \\
\text { Community Unconditional } \\
\text { Grant }\end{array}$ & $\begin{array}{l}\text { Dana digunakan untuk dua tujuan } \\
\text { yang umum: pembelian modal } \\
\text { (kapital) dan pembayaran berulang } \\
\text { (operasional) }\end{array}$ & $\begin{array}{l}\text { Alokasi Formula: } \mathbf{1 0 0} \% \\
\text { - } 60 \% \text { Jumlah Penduduk } \\
\text { - } 10 \% \text { Luas Wilayah } \\
\text { - } 30 \% \text { Indeks Kesulitan Konstruksi }\end{array}$ \\
\hline
\end{tabular}

Sumber: UNDP (2019)

Tabel 2. Perbandingan Karakteristik Desa Bengkaung dan Pusuk Lestari

\begin{tabular}{|c|c|c|}
\hline & Bengkaung & Pusuk Lestari \\
\hline Penduduk & 3475 & 1182 \\
\hline Penduduk Usia 0-4 Tahun & 323 & 109 \\
\hline Penduduk Miskin & 61 & 17 \\
\hline Luas Wilayah (Km2) & 0,52 & 0,64 \\
\hline IKG & 41,4 & 39,3 \\
\hline Jumlah Dusun & 7 & 4 \\
\hline Jumlah Perangkat Desa & 7 & 7 \\
\hline Jumlah Posyandu & 6 & 4 \\
\hline \multicolumn{3}{|l|}{ APBDes } \\
\hline Dana Desa & 652.667 .000 & 628.278 .000 \\
\hline Alokasi Dana Desa & 667.368 .500 & 600.144 .000 \\
\hline Bagi Hasil Pajak dan Retribusi Desa & 41.369 .000 & 41.126 .400 \\
\hline Bantuan Keuangan Provinsi & 0 & 0 \\
\hline Bantuan Keuangan Kabupaten & 0 & 0 \\
\hline \multicolumn{3}{|l|}{ Pendapatan Asli Desa } \\
\hline Hibah, Sumbangan, Swadaya Masyarakat, dan lainnya & 0 & 0 \\
\hline Total Pendapatan & 1.361 .404 .500 & 1.269 .548 .400 \\
\hline Dana Desa per penduduk & 187.818 & 531.538 \\
\hline Total Pendapatan per penduduk & 391.771 & 1.074 .068 \\
\hline
\end{tabular}

Sumber: World Bank (2017)

Tabel 3. Perbandingan Anggaran Desa Bengkaung dan Pusuk Lestari

\begin{tabular}{|l|r|r|r|r|}
\hline & \multicolumn{2}{|c|}{ Bengkaung } & \multicolumn{2}{c|}{ Pusuk Lestari } \\
\cline { 2 - 5 } & Total Anggaran & $\begin{array}{c}\text { Anggaran } \\
\text { Per Penduduk }\end{array}$ & Total Anggaran & $\begin{array}{c}\text { Anggaran } \\
\text { Per Penduduk }\end{array}$ \\
\hline Pelayanan Kesehatan & $61,083,400$ & & $47,096,000$ & \\
\hline - Posyandu & $22,500,000$ & 69,018 & $35,096,000$ & 340,738 \\
\hline Pelayanan Pendidikan & $64,092,500$ & & $20,147,356$ & 47,689 \\
\hline - PAUD & $5,000,000$ & 30,675 & $2,456,000$ & \\
\hline
\end{tabular}

Sumber: World Bank (2017) 


\section{ILUSTRASI GAMBAR}

Gambar 1. Kerangka Konseptual Perbaikan Formula Dana Desa

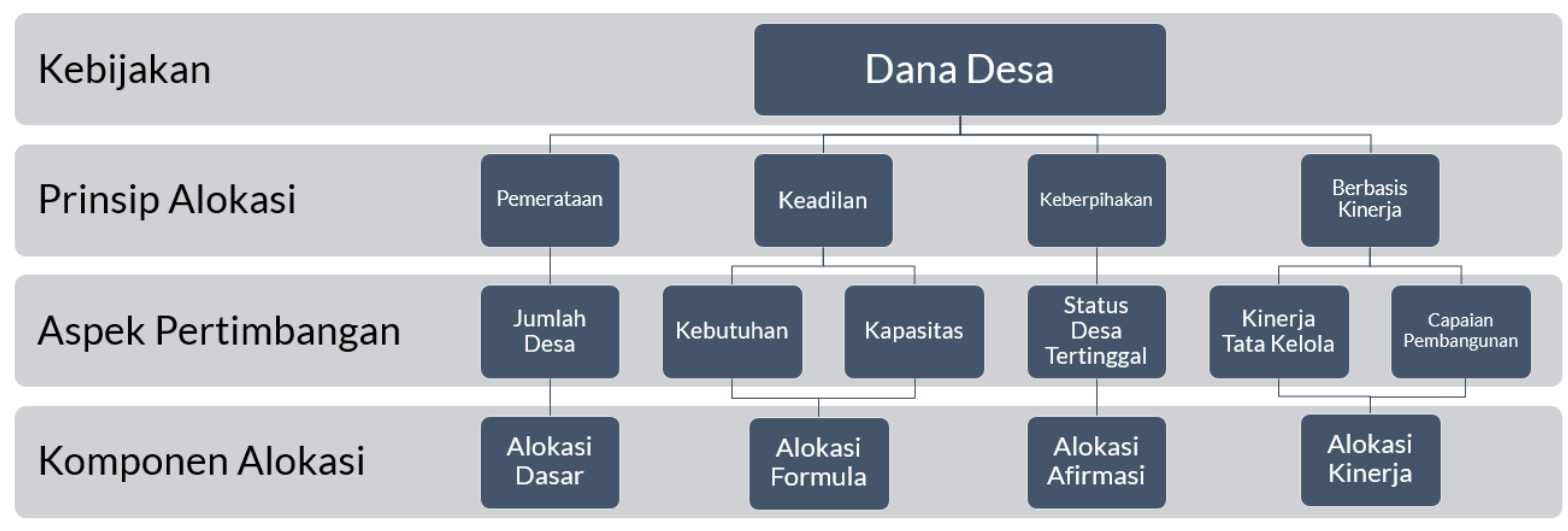

Sumber: LPEM FEB UI (2020)

Gambar 2. Kesalahan Alokasi Dana Desa Per Pulau

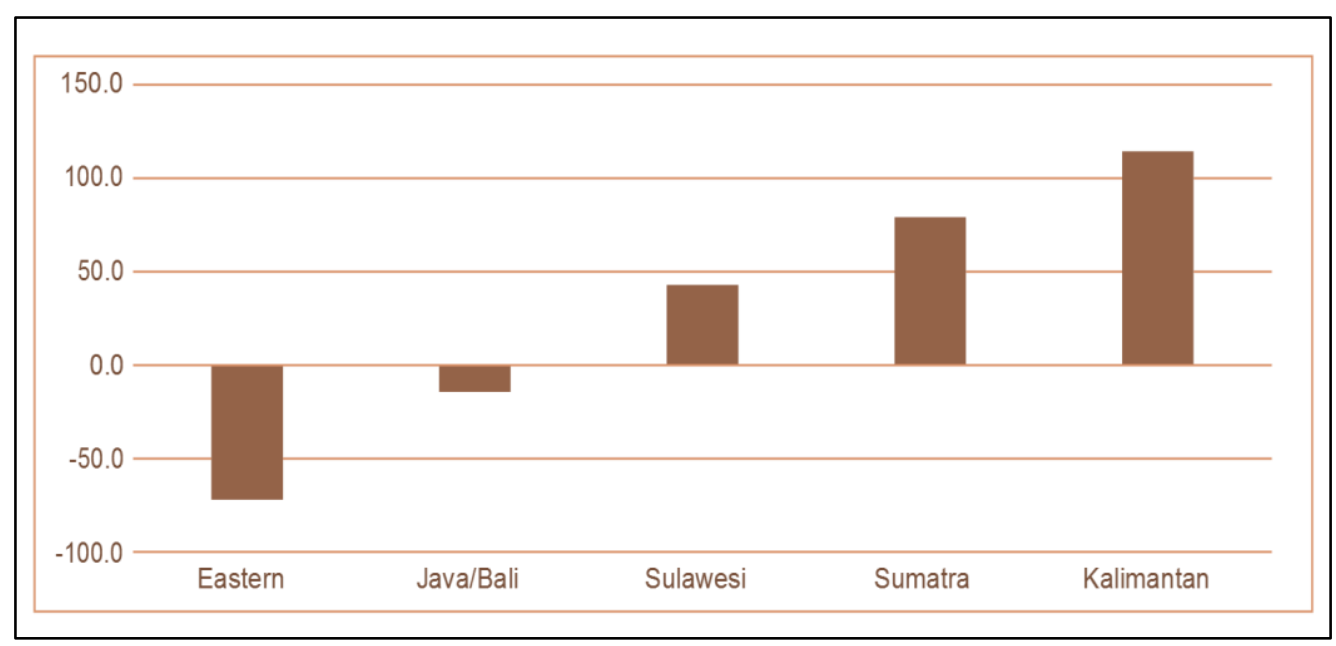

Sumber: Lewis (2015)

Gambar 3. Sebaran Desil Alokasi Dana Desa 2015 dan Jumlah Penduduk Miskin dan Hampir Miskin

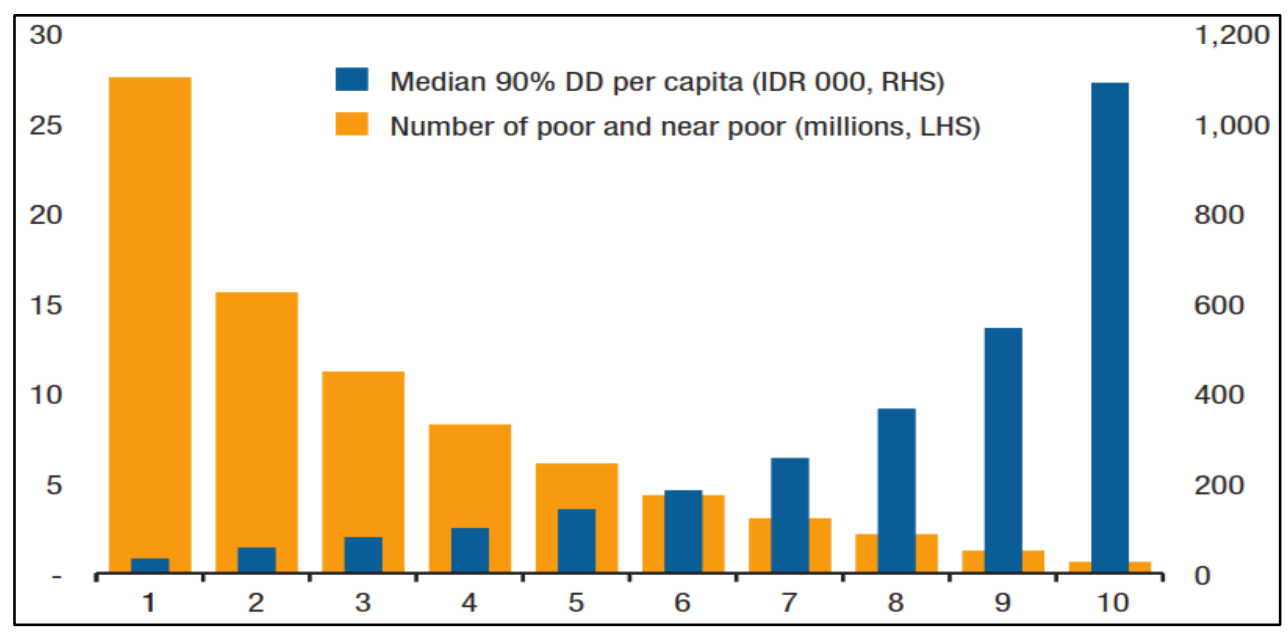

Sumber: KOMPAK (2017) 


\section{Gambar 4. Roadmap Formula Dana Desa Jangka Menengah}

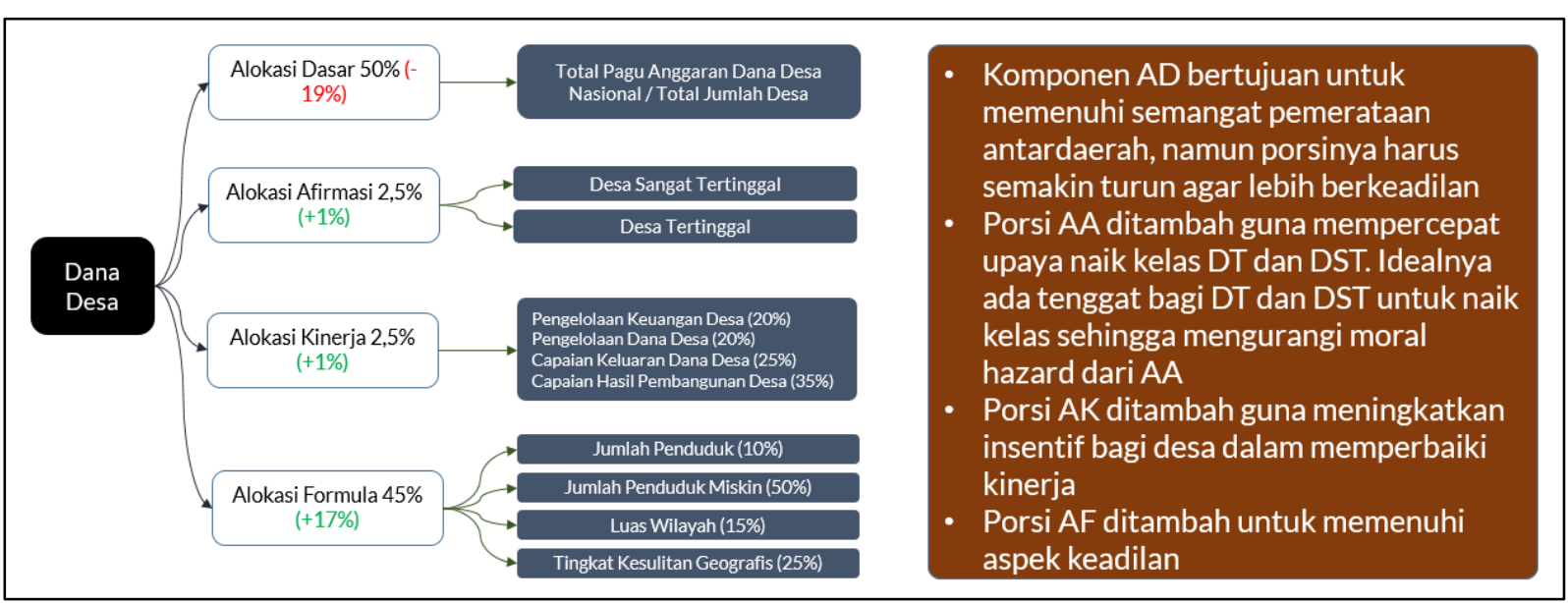

Sumber: LPEM FEB UI (2020) 